\title{
The Role of Financial Management on Productivity of the Refinery Case Study: Khangiran Gas Refinery of Iran
}

\author{
Seyed Gholam Hossein Hashemi Nassab ${ }^{1}$ \\ ${ }^{1}$ Gaz Refinery of Shahid Hashemi Nejad, Iran \\ Correspondence: Seyed Gholam Hossein Hashemi Nassab, E-mail: hh.nasab@yahoo.com
}

Received: February 20, 2016

Accepted: March 25, 2016

Online Published: March 30, 2016

doi:10.5539/mas.v10n6p44

URL: http://dx.doi.org/10.5539/mas.v10n6p44

\begin{abstract}
This study evaluated the management strategy of Khangiran Gas Refinery of Iran for Financial Management and investigated the role of financial management on productivity. The respondents were ninety seven employees of Khangiran Gas Refinery. Survey questionnaire included 10 items with 5 point Likert scale was used in the study. Data was analyzed with using SPSS-19. Results showed the highest weighted mean was "the specified budget for any project was done in last years" with 3.84 mean score and verbal interpretation of "effective" while lowest mean was 3.51 with verbal interpretation of "effective" for the statement "Before doing any projects budget analysis is done carefully." and there was a significant relationship between the financial management and productivity of the refinery; therefore the increase of the financial management leads to the increase of the refinery productivity.
\end{abstract}

Key words: financial management, productivity, strategic management

\section{Introduction}

Business concern needs finance to meet their requirements in the economic world. Any kind of business activity depends on the finance. It is because that called as lifeblood of business organization. Whether the business concerns are big or small, they need finance to fulfill their business activities. In the modern world, all the activities are concerned with the economic activities and very particular to earning profit through any venture or activities. The entire business activities are directly related with making profit. Hence finance may be called as capital, investment, fund etc., but each term is having different meanings and unique characters. Increasing the profit is the main aim of any kind of economic activity.

Oil and gas refiners have run into some new and difficult challenges in recent years. Among them are the requirements for large capital expenditures and increased hydrogen usage for low sulfur fuels that are mandated by new environmental standards. Gasoline shortages caused by the hurricane damage in the United States Gulf Coast region has prompted news reports highlighting increased profit margins for refineries. Typically these margin increases are represented in absolute terms on a per gallon basis, and are not normalized by the cost of crude oil, which must be paid by the refiner (Schowalter, 2010).

Although the price is the most important factor to refinery, this study dwelt also other factors by means of survey to examine the refinery's increasing revenue by Operations Management.

The aim of this study is to determine the Operations Management of Khangiran Gas Refinery of Iran which maybe a basis to increase productivity. The researcher surveyed the Operation Management in terms of financial management and will find a model for improving productivity of Khangiran Gas Refinery.

\section{Literature Review}

\subsection{Financial Management}

Financial management is an integral part of overall management. It is concerned with the duties of the financial managers in the business firm.

The term financial management has been defined by Solomon, "It is concerned with the efficient use of an important economic resource namely, capital funds." The most popular and acceptable definition of financial management as given by S.C. Kuchal is that "Financial Management deals with procurement of funds and their effective utilization in the business". 
Financial management is one of the important parts of overall management, which is directly related with various functional departments like personnel, marketing and production. Financial management covers a wide area with multidimensional approaches.

Thus, Financial Management is mainly concerned with the effective funds management in the business. In simple words, Financial Management as practiced by business firms can be called as Corporation Finance or Business Finance.

\subsection{Productivity}

Productivity is an average measure of the efficiency of production. Productivity is a ratio of production output to what is required to produce it (inputs of capital, labor, land, energy, materials, etc.). The measure of productivity is defined as a total output per one unit of a total input. We see that as a measure of the average productivity is often difficult to interpret correctly.

These definitions are short but too general and insufficient to make the phenomenon productivity understandable. A more detailed theory of productivity is needed, which explains the phenomenon productivity and makes it comprehensible. In order to obtain a measurable form of productivity, operationalization of the concept is necessary. In explaining and operationalizing a set of production models are used. A production model is a numerical expression of the production process that is based on production data, i.e. measured data in the form of prices and quantities of inputs and outputs.

It is advisable to examine any phenomenon whatsoever only after defining the entity the phenomenon under review forms part of. Hence, productivity cannot be examined as a phenomenon independently but it is necessary to identify the entity it belongs to. Such an entity is defined as production process and its ability to generate incomes.

The benefits of high productivity are manifold. At the national level, productivity growth raises living standards because more real income improves people's ability to purchase goods and services, enjoy leisure, improve housing and education and contribute to social and environmental programs. Productivity growth is important to the firm because more real income means that the firm can meet its (perhaps growing) obligations to customers, suppliers, workers, shareholders, and governments (taxes and regulation), and still remain competitive or even improve its competitiveness in the market place.

\subsection{Khangiran Gas Refinery}

Khangiran is the major gas field in North East Iran, near the Turkmenistan border, and it supplies gas to North Eastern provinces through Hasheminejad refinery plant. This gas field has been operational since late 1970s and consists of 54 gas wells, 3 gas gathering centers and a central measuring station which is the connection point to the refinery.

Shahid Hashemi nejad Gas refinery produces $\% 10$ of the required gas of the country. It is the only gas refinery in the east of Iran. Thus, its constant production and productivity makes it as an important and strategic one in Iran. This refinery is the biggest and the oldest manufacturer of Sulfur in Iran, the Sulfur is exported to other countries. The condensation products are sent to oil refineries and petro chemical companies to be changed to other products and goods. Since the oil and gas resources are nearly to be finished, the responsibility of the management is to use appropriate strategies and plans to increase the rate of productivity and decrease the rate of wastages.

\subsection{Research Purpose and Hypothesis}

Generally, the study aimed to determine the effective level of management strategy of Khangiran Gas Refinery of Iran in terms of financial management; also investigate relationship between the financial management and productivity of the refinery. Therefore the question and Hypothesis of below is presented:

Question: What is the effective level of management strategy of financial management as regards increasing production.

Hypothesis: There is significant relationship between the financial management and productivity of the refinery.

\section{Conceptual model of Research:}

The researcher used the input process and output model. The conceptual paradigm presented in the succeeding page shows sets of inputs which is the profile of the respondents in terms of age, educational attainment and length of service, and the management practices of production, marketing, human resource and financial which are subjected to a process. These are designed to attain certain outputs to satisfy the objectives of the study. 
In the context of the study, the factors in the operations management of Khangiran Gas refinery are included to define its paradigm as shown in the diagram.

Under the process, the presentation starts with the evaluation, data gathering, and analysis using appropriate statistical treatment. The developed conceptual framework is a model to find out about the ways of increasing productivity in refinery by operations management. Finally, it is expected that given the proper process, management model for gas refinery will be proposed. The research paradigm of the study is shown on the next page.

Input

Process

Output

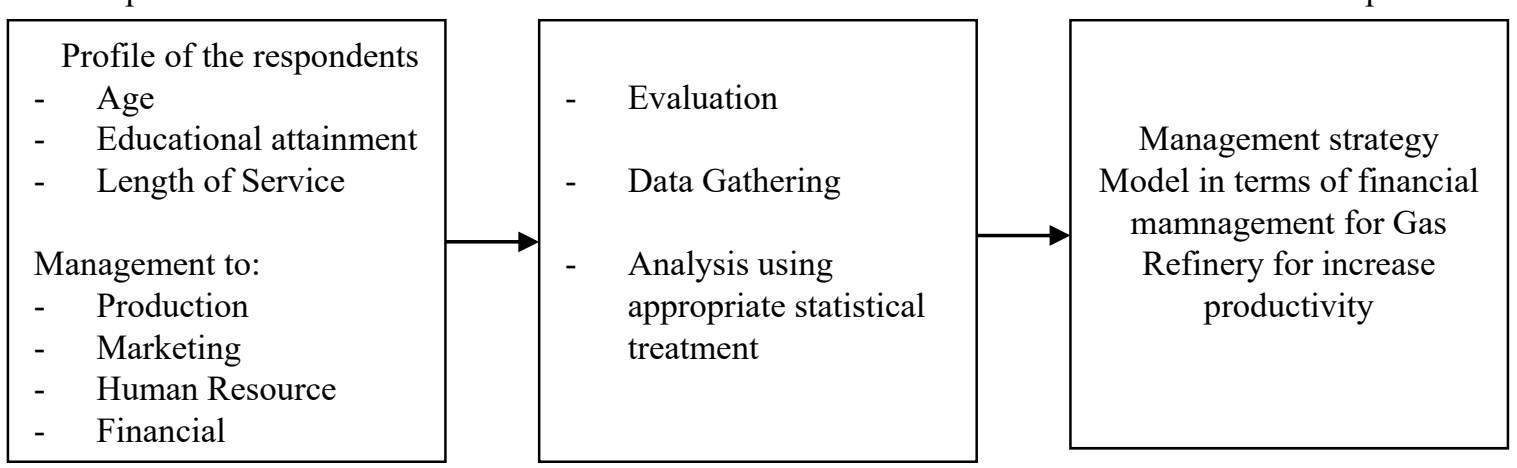

\section{Methodology}

The researcher used a cross-sectional survey design. A cross-sectional survey design involves obtaining information from a wide section of respondents at once without need to follow up the respondents for further information (Amin, 2005). Thus, data collection was done over a short period. Quantitative and qualitative approaches were used with the view of triangulation as being appropriate for the study.

The study site was done in Khangiran Gas Refinery, Sarakhs, Iran. Khangiran is the major gas field in North East Iran, near the Turkmenistan border, and it supplies gas to North Eastern provinces through Khangiran refinery plant. This gas field has been operational since late 1970s and consists of 54 gas wells, 3 gas gathering centers and a central measuring station which is the connection point to the refinery.

The respondents of the study were ninety seven (97) employees of Khangiran Gas Refinery; All of the respondents were male; age range of them is between 30 to 60 years old. Majority of the respondents were bachelor degree holders with $77 \%$ while the rest $23 \%$ of the respondents already had their masters degree. About Length of Service, Majority of the respondents had 10 to 20 years of service in the company with 47 or $49.47 \%$, followed by 39 or $41.05 \%$ of the respondents who rendered their 21 to 30 years in service, while the least respondents had been working in the company for more than 30 years o 9 or $9.47 \%$. Convenience sampling technique was utilized in the study because all of the respondents were easily available and identified.

The data gathering instrument used in the study was self-construct questionnaire with 10 items. The research instrument is composed of two parts.

Part I deals with the demographic profile of the respondents that includes respondents' age, educational attainment and length of service and Part II deals with the level of effectiveness of the operation management of Khangiran Gas Refinery in increasing its productivity in terms of marketing management. They were measured on 5-point Likert type scales, ranging from highly effective, effective, moderately effective, less effective, and not effective. To ensure validity of research instruments, the draft instrument was subjected to scrutiny by the supervisor, other lecturers in the department and colleagues who had knowledge in research and industry. Their comments and recommendations were used to improve the final copy of the instruments. Also, the pilot testing for the reliability and validity of the questionnaire was done and some of the items were clarified or changed to be more representative of the intended constructs.

For gathering data, the researcher get a permission letter from the Khangiran Gas Refinery, which was used to seek permission of managers in charge in order to administer questionnaire to employers of Khangiran Gas Refinery, and heads of departments. The raw data was field edited, later coded and analyzed.

Analysis of the data was done by the use of SPSS software with using descriptive statistics, Correlation analysis and regression model. 


\section{Results}

Results of research question and hypothesis analysis is presented in follow.

Question: What is the effective level of management strategy of financial management as regards increasing production..

Table 1 shows the effective level of management strategy as regards Increasing Production in Terms of Financial Management.

Table 1. Effective level of management strategy as regards Increasing Production in Terms of Financial Management

\begin{tabular}{|c|c|c|c|}
\hline \multicolumn{2}{|c|}{ Items } & \multirow{2}{*}{$\begin{array}{l}\text { Weighted } \\
\text { Mean }\end{array}$} & \multirow{2}{*}{$\begin{array}{l}\text { V.I. } \\
\text { Effective }\end{array}$} \\
\hline 1. & Before doing any projects budget analysis is done carefully. & & \\
\hline 2. & Selecting the projects is based on the technology and budget. & 3.60 & Effective \\
\hline 3. & Financial plans are done carefully. & 3.65 & Effective \\
\hline 4. & The specified budget for any project is done in last years. & 3.84 & Effective \\
\hline 5. & There is effectiveness in financial plans of the organization. & 3.67 & Effective \\
\hline 6. & There is a regular analysis in business management. & 3.53 & Effective \\
\hline 7. & For emergency projects supplement funding is considered. & 3.76 & Effective \\
\hline 8. & Paying and funding evaluation is done appropriately. & 3.84 & Effective \\
\hline 9. & $\begin{array}{l}\text { New funding parameters are used to make sure of the effectiveness of the } \\
\text { resource structure. }\end{array}$ & 3.53 & Effective \\
\hline 10. & Financial resources are used for long term and short term plans. & 3.70 & Effective \\
\hline & Grand Mean & 3.66 & Effective \\
\hline
\end{tabular}

Legend: Highly Effective: 4.51-5.00; Effective: 3.51-4.50; Moderately Effective: 2.51-3.50; Less Effective: 1.51-2.50; Not Effective: 1.00-1.50.

ten statements were included in the table 1 and The highest weighted mean was "the specified budget for any project is done in last years" with 3.84 mean score and verbal interpretation of "effective" while lowest mean was 3.51 with verbal interpretation of "effective" for the statement "Before doing any projects budget analysis is done carefully". It can be noticed that respondents seemed that having financial plan and budget of company ahead of time seemed effective as management strategy for increasing production of the company in terms of financial management. For instance, the company allotted financial budget and plans for the next year operations and developments as a financial management strategy for the company. This factor is seemed effective for the respondents to increase the production of the company. On the other hand, although a year before the plan, careful analyses of the plans to its budget seemed less the last effective factor that helps for the increase of company's production. Overall, grand mean 3.66 shows that the level of management strategy of company in terms of financial management rated "effective" for the respondents to increase company's production. It shows that, for the respondents, the financial management done by the company is effective and it helped to increase the production of the company through planning the budget ahead of time (a year before). The plans and developments of the company were considered so that production of the company will improve and increase.

Hypothesis: There is a significant relationship between the financial management and productivity of the refinery.

To investigate this hypothesis it is appropriate to use the linear regression model instead of correlation coefficient. The fitted model for this hypothesis is as follows:

$$
Y_{i}=\beta_{0}+\beta_{1} \text { Financial management } t_{i}+\varepsilon_{i}
$$

Table 2 summarizes the regression model of this hypothesis.

Table 2. Model Summary ${ }^{\mathrm{b}}$

\begin{tabular}{llllll}
\hline Model & R & R Square & Adjusted R Square & Std. Error of the Estimate & Durbin-Watson \\
\hline 1 & $.213^{\mathrm{a}}$ & .105 & .105 & 18.23657 & .562 \\
\hline
\end{tabular}

a. Predictors: (Constant), Financial management; b. Dependent Variable: $Y$ 
According to table 2 the correlation coefficient between financial management and productivity of the refinery is 0.213 , thus there is a significant relationship between these two variables. In other words the increase of the financial management leads to the increase of the refinery productivity. Based on data presented in table 2 the coefficient of determination is 0.105 which indicates that $10.5 \%$ of the changes in dependent variable (productivity of the refinery) originated from the independent variable (financial management).

In order to evaluation the following hypotheses $\left\{\begin{array}{l}\beta_{1}=0 \\ \beta_{1} \neq 0\end{array}\right.$ an Anova test was done and indicated that the regression coefficient wouldn't be zero $(F=81.117$, $p$-value $<0.05)$. So the efficacy of model would be accepted at $95 \%$ level of significance. In the table 3 coefficients of the regression model are presented and showed that with the increase in the financial management the productivity of the refinery will increase.

Table 3. Coefficientsa

\begin{tabular}{lllllr}
\hline Model & \multicolumn{4}{l}{ Unstandardized Coefficients } & \multicolumn{2}{l}{ Standardized Coefficients } \\
& $\mathrm{B}$ & Std. Error & Beta & t & Sig. \\
\cline { 2 - 6 } & 1 (Constant) & 104.810 & 07.654 & & 06.569 .000 \\
$\quad$ Financial management & 2.218 & .139 & .213 & 07.118 .000 \\
\hline
\end{tabular}

a. Dependent Variable: Y

$$
\text { riable: Y }
$$

According to table 3 the significant level of financial management is 0.00 which is lower than 0.05 , so there is a significant relationship between the financial management and productivity of the refinery at $95 \%$ level of significance. Thus the following model can be presented for the hypothesis:

$$
Y_{i}=114.18+2.218 * \text { Financial management } t_{i}
$$

This model showed that by increasing one unit of financial management, 2.218 units will be added to the productivity of the refinery. Consequently, there is a positive significant relationship between the financial management and productivity of the refinery.

\section{Discussion and Conclusion:}

This study evaluated the management strategy of Khangiran Gas Refinery Iran for Financial Management and investigated the role of financial management on productivity. Ninety seven (97) respondents presently working in Khangiran Gas Refinery were included in the study. The results of the effectiveness level of management strategy of Financial Management shows the highest weighted mean was "the specified budget for any project is done in last years" with 3.84 mean score and verbal interpretation of "effective" while lowest mean was 3.51 with verbal interpretation of "effective" for the statement "Before doing any projects budget analysis is done carefully". Also the results show that there is a significant relationship between the financial management and productivity of the refinery.

Based on the results of the financial management two following chart is presented:

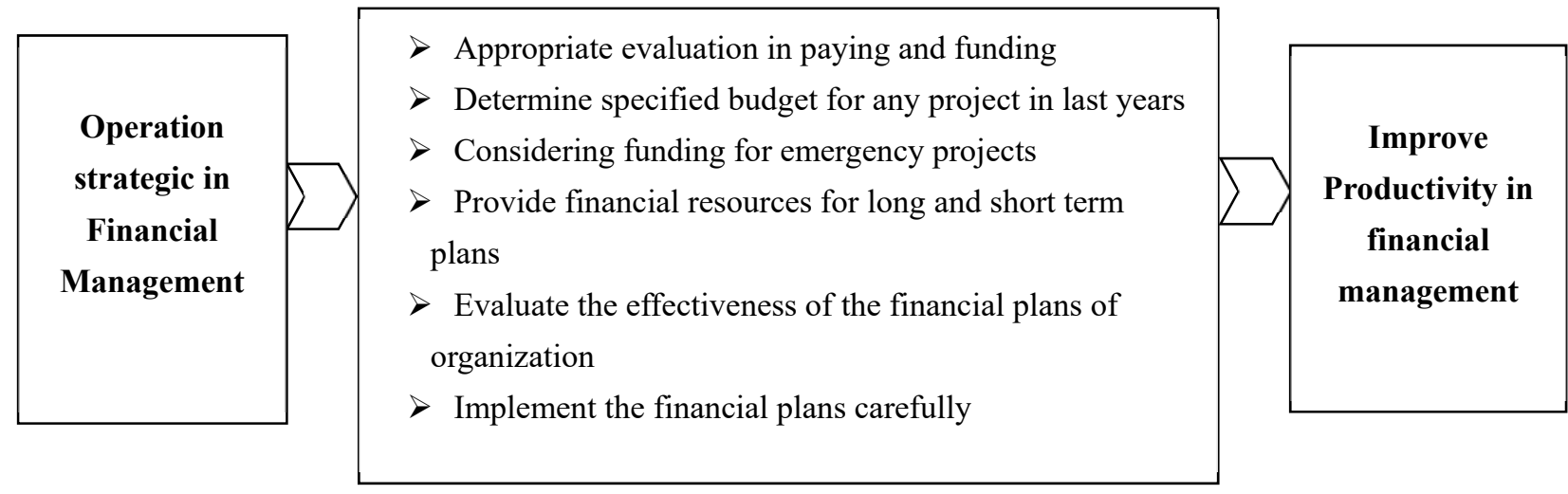

Also regarding the notion of the financial management and results the following are recommended:

1) The advantages and disadvantages of each financial program should be investigated carefully, whether they are useful or useless? Sometimes because of the environmental matters and the social promises of the refinery some financial plans may not be convincing but should be done for the sake of healthy society. 
2) Financial parameters are one of the most important factor in productivity of the refinery, thus, they should be recognized in advance.

\section{References}

Abernathy, F., Dunlop, J., Hammond, J., \& Weil, D. (2000). Control your inventory in a world of lean retailing. Harvard Business Review, November/December, 169-176.

Aseeri, A., \& Bagajewicz, M. J. (2004). New measures and procedures to manage financial risk with applications to the planning of gas commercialization in Asia. Computers \& Chemical Engineering, 28(12), 2791-2821.

Becker, B. E., \& Huselid, M. A. (2006). Strategic human resources management: where do we go from here? Journal of Management, 32(6), 898-925.

Chalaka, R. (2012). Hitachi Data system Productivity for Oil Company, Zycko Inspiring Innovation.

Chandler, G. N., \& McEvoy, G. M. (2000). Human resource management, TQM, and firm performance in small and medium enterprises. Entrepreneurship Theory and Practice, 25(1), 43-47.

Cua, K. O., McKone, K. E., \& Schroeder, R. G. (2001). Relationships between implementation of TQM, JIT, and TPM and manufacturing performance. Journal of Operations Management, 19(2), 675-694.

Datta, D., Guthrie, J., \& Wright, P. (2005). Human resource management and labor productivity: does industry matter? Academy of Management Journal, 48, 135- 145.

Diamantopoulos, A., \& Siguaw, J. A. (2006). Formative versus reflective indicators in organizational measure development: a comparison and empirical illustration. British Journal of Management, 17(4), 263-282.

Dwyer, G. (2002). Quality management initiatives and people management strategies. International Journal of Quality and Reliability Management, 19(3), 524-539.

Hendricks, K. B., \& Singhal, V. R. (2001). Firm characteristics, total quality management, and financial performance. Journal of Operations Management, 19, 269-285.

Jung, T., \& Wickrama, K. A. S. (2008). An introduction to latent class growth analysis and growth mixture modeling. Social and Personality Psychology Compass, 2(1), 302-317.

Lemak, D. J., \& Reed, R. (2000). An application of Thompson's typology to TQM in service firms. Journal of Quality Management, 5, 67-83.

Li, S., Rao, S. S., Ragu-Nathan, T. S., \& Ragu-Nathan, B. (2005). Development and validation of a measurement instrument for studying supply management practices. Journal of Operations Management, 23(6), 618-641.

Loan, L. (2013). How to Increase Productivity-Choosing The Right Project Management Software, Super Articles. Retrieved from http://www.sooperarticles.com/business-articles/project-management-articles/ how-increase-productivity-choosing-right-project-management-software-1160357.h

Nahm, A., Vonderembse, M. A., \& Koufteros, X. (2003). The impact of organizational structure on time-based manufacturing and performance. Journal of Operations Management, 21(3), 281-306.

Singh, S. K. (2010). Ways to Improve Productivity in Manufacturing Industry, Article Base.

Tabije, I. (2007). Productivity and Production Management, Ezine Articles.

Wall, T. D., \& Wood, S. J. (2005). The romance of HRM and business performance, and the case for big science.

\section{Copyrights}

Copyright for this article is retained by the author(s), with first publication rights granted to the journal.

This is an open-access article distributed under the terms and conditions of the Creative Commons Attribution license (http://creativecommons.org/licenses/by/3.0/). 